\author{
Aušra Pociené \\ The General Jonas Žemaitis Military Academy of Lithuania
}

\title{
Possibilities to Attract Lithuanian Young People to Permanent Compulsory Primary Military Service
}

\begin{abstract}
Even though permanent compulsory primary military service is an unquestionable military duty, it is very important that it has the support of the public. The question of what motivates young people to volunteer to do their PCPMS will remain relevant as long as the service is in place. This article attempts to identify ways to attract young people to military service. It analyses the value-based context of the Lithuanian public, specifically highlighting the priorities of the younger generation. This allows us to understand what forms the basis of young people's decisions and the things they would consider in making up their minds to do PCPMS. The article contrasts the views of conscripts and civil young people towards PCPMS, the army and the defence of the country. It aims to develop an understanding of why the former choose PCPMS voluntarily. The article relies on data from quantitative studies - the opinion polls of young Lithuanians (males aged 15-30) and conscripts - conducted by researchers at the Centre for Strategic Research at the General Jonas Žemaitis Military Academy of Lithuania in 2015-2017. It also relies on data from the European Values Study performed in Lithuania in 2008.
\end{abstract}

\section{Introduction}

Permanent compulsory primary military service (PCPMS) was reintroduced in Lithuania in 2015 following a hiatus of nearly eight years. This was done in response to threats to Lithuanian security that appeared after the military conflict between Russia and Ukraine. Conscripts were supposed to complete military units of the Lithuanian armed forces (LAF) that were understaffed at the time. The public diverged in its reception of the very fact of reintroducing PCPMS, and there were those who supported it and those who opposed it. On the one hand, this can be explained by the rather short period of time (a few months) it took to turn the idea of reintroducing conscript service into a concrete decision and society did not have enough time to get used to it. There were many discussions regarding the criteria (such as age limits, university

\footnotetext{
*Aušra Pociene, $P h D$, is a senior research fellow at the Research Centre of the General Jonas Žemaitis Military Academy of Lithuania. Mailing address: Šilo g. 5a, LT-10322 Vilnius, Lithuania; phone: +370 52103571 ; e-mail: ausra.pociene@mil.lt.
}

DOI: 10.2478/lasr-2018-0013 
studies and so on) and the method (the lottery principle) of picking out those liable to serve. On the other hand, the (un)willingness to do PCPMS can be linked to matters that are more fundamental, such as questions of the perception of values and civil duty. According to data from the Military Duty and Recruitment Service, the number of young people volunteering for PCPMS is decreasing, albeit marginally. In 2015, 3,010 young people were delivered for duty, of whom 2,133 reported for duty voluntarily and 877 filed priority applications. In 2016, the number was 3,000, of whom 2,044 reported for duty voluntarily and 956 filed priority applications. In 2017, the number was 3,507, of whom 1,912 reported for duty voluntarily and 1,542 filed priority applications, while 53 young people were conscripted under the compulsory procedure.

This article deals with the question of what the main factors and levers were that helped attract young people to do permanent compulsory primary military service in 2015-2016, and will help do so in the future, could be. To answer this question, on the one hand, the article reviews the overall valueorientation of young people in Lithuania, the interior motives and priorities that define their life choices. On the other hand, based on the data of surveys made by the Centre for Strategic Research of the Military Academy of Lithuania $(\mathrm{MAL})^{1}$, analysis is made to identify the motives that caused the first conscripts to join the Lithuanian army, aiming to determine their attitudes toward the service, the Lithuanian army and the national defence in general.

The subject of the article follows issues that are dealt with by the Security Policy and Social Research Department of the General Jonas Žemaitis Military Academy of Lithuania (MAL). The year 2014 saw the issuing of a publication titled 'Analysis of Volunteer Troops' Opinions of Service in the Lithuanian Armed Forces' (Lith. Kariu savanoriu požiürio ị tarnybą Lietuvos kariuomenëje analizè)', which aimed to identify the types of motivations of volunteer troops. In 2015, a scientific study named 'Motivation to Serve in the Lithuanian Armed Forces' (Lith. Motyvacija tarnauti Lietuvos kariuomeneje) $)^{3}$ was published, addressing the matter of motivations to serve in the army through a survey of troops in the professional services, volunteer soldiers and the Lithuanian public. The tradition of motivational studies at the MAL emerged over a decade ago. One notable mention is an integrated study of the soldier's profession by Jürate Novagrockiene and the

\footnotetext{
${ }^{1}$ As of October 2017, the Centre for Strategic Research of the Institute of Military Sciences was reorganised to become the Security Policy and Social Research Department of the Centre for Science.

${ }^{2}$ Vileikienė E., Pocienė A., Aleknevičienė J. (2014-2015), „Karių savanorių požiūrio ị tarnybą Lietuvos kariuomenèje analize்", Lietuvos metinè strategine apžvalga, vol. 13, p. 245-264.

${ }^{3}$ Vileikienè E., Pocienè A., Aleknevičienè J. (2015), Motyvacija tarnauti Lietuvos kariuomeneje, Vilnius: Generolo Jono Žemaičio Lietuvos karo akademija.
} 
follow-up publication titled 'The Image of the Soldier's Profession in Lithuania: the Opinion of Soldiers, the Public and Young People' (Lith. Kario profesijos ịvaizdis Lietuvoje: kariu, visuomenes ir jaunimo požiüris $)^{4}$ that follows theoretical assumptions by Ronald Inglehart and Fabrizio Battistelli in a bid to identify the opinions that professional soldiers, the public and the young have of the armed forces.

The topics of attracting and retaining young people in the armed forces are addressed in works by foreign authors as well. There, the focus lays on matters of soldier motivation and successful recruitment. For instance, the Israeli researchers Meidad Avidar and Shira Rivnai-Bahir analyse how the changes in values of the Israeli public over the past decades have affected young people's attitude towards military service. A study by Swedish researcher Erik Hedlund of the motivations of Swedish troops to participate in peacekeeping missions is worth mentioning too. Czech researchers Eva Pavlikova and Jitka Laštovkova examine in their studies what motivates soldiers to serve in the armed forces and what their professional values are. Norwegian researcher Nina Hellum investigates how doing military service could become an interim step in joining the professional military and following a career. Attracting and keeping cadres in professional military service is also the focal point of attention in the work of Swedish researchers Johan Österberg, Emma Jonsson and Anna-Karin Berlung. Work by researchers from neighbouring Estonia merits a mention as well. For instance, Kasearu, Tiia-Triin Truusa analyses the factors that boost and dampen conscript motivation during the first few months of service ${ }^{5}$.

The novelty of this article lies in the fact that the matter of motivation to serve in the military, or rather do PCPMS, is addressed in a wider context of values, revealing the environment in which young people are raised and socialise, what their priorities in life are and how, on the basis of these things, the possibilities of attracting them to PCPMS can be assessed and planned for. The article does not aim to provide specific recommendations as to what measures should be employed ${ }^{6}$ to attract more conscripts at a particular time, but rather tries to identify and discuss the main elements (the value context,

\footnotetext{
${ }^{4}$ Novagrockienė J. (2009-2010), „Kario profesijos ịvaizdis Lietuvoje: karių, visuomenès ir jaunimo požiūris", Lietuvos metinè strateginè apžvalga, vol. 8, p. 193-216.

${ }^{5}$ The review of the issues under analysis by foreign researchers was done on the basis of the agendas of the $13^{\text {th }}$ and $14^{\text {th }}$ ERGOMAS (European Research Group on Military and Society) conference $(2015,2017)$.

${ }^{6}$ It should be noted that, having conducted surveys of conscripts and focus groups (young people, the public) in 2016, the Centre for Strategic Research of the MAL has repeatedly presented its data to the DS and the Lithuanian Armed Forces, suggesting specific recommendations to attract young people to PCPMS: from improving concrete aspects within PCPMS (such as developing chiefs' competences, ensuring discipline, improving infrastructure, and so on) to suggestions for improved efficiency of external communication. However, it should be emphasised that recommendations may differ from case to case (depending on the year, the current geopolitical context, the PCPMS organisation per se, the specific military unit).
} 
an external assessment of threats, attitudes towards the defence of the country, the perception of the army's role, and so on) that need to be considered time and time again when evaluating the possibilities to attract young people to the armed forces. This kind of analysis relies on descriptive statistics as it allows the general tendencies to be revealed, and sometimes, to question the formulations permitting, to make a comparison among the different groups.

The article relies on data from seven quantitative representative surveys. For the purposes of analysing the general value context of the public and young people, reference is made to the 2008 European Values Study (no data are available yet for 2017). Analysis of public and youth opinion of the armed forces, service in the military and the disposition to defend the country is made on the basis of data from surveys of the Lithuanian public (2015 and 2017) and Lithuanian males aged 15 to 30, in 2016 and 2017. Analysis of the opinions of conscripts is based on two surveys of 'first-wave' conscripts who entered service right after the reinstatement of PCPMS, at the beginning and at the end of their service (2016). Figure 1 shows the distribution of these surveys over time.

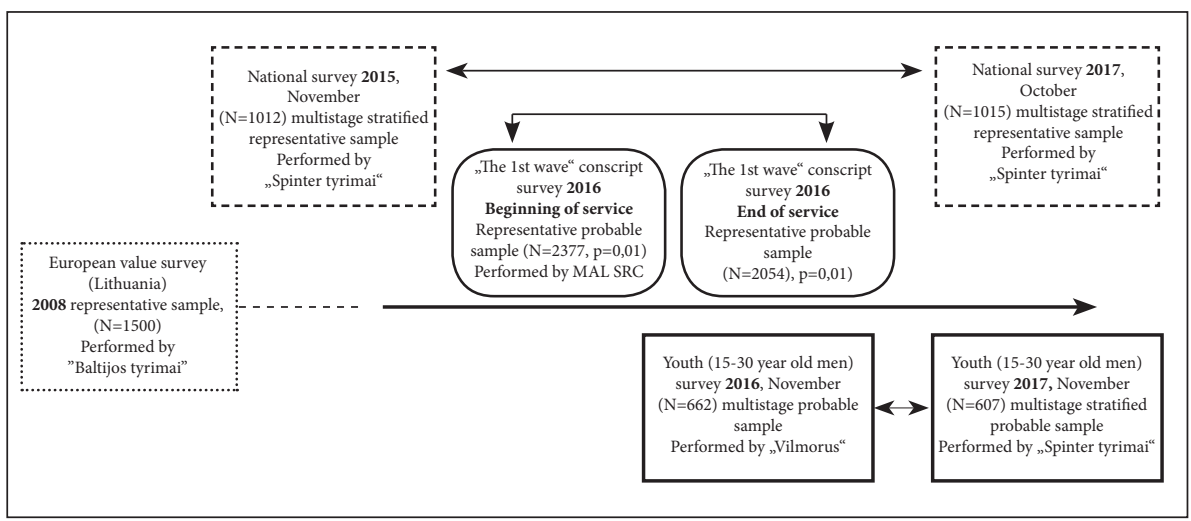

Figure 1. Quantitative surveys providing data for the article

The article consists of four chapters. Chapter one contains an overview of theoretical assumptions for the interpretation of the data, introducing the modernisation theory according to Ronald Inglehart and discussing the classification of types of soldier motivation by Fabrizio Battistelli. Chapter two reviews a portrait of values of the Lithuanian public with the priorities of young people highlighted. Chapter three refers to data from a CSR survey of the Lithuanian public, young people and conscripts to analyse the opinions of these groups on PCPMS, the Lithuanian Armed Forces and defending the country. The article ends with conclusions. 


\section{Values as Behaviour-Shaping Factors}

Various social theories present different definitions of values. This article is not based on any particular definition but rather follows a broader assumption that values are internalised motivations and orientations that govern the behaviour of a human being. They are simply invisible latent constructors that can be judged by how a person behaves and what their priorities are. Sociological studies of values are represented best by the European Values Study (EVS) that has been conducted in various European countries once every nine years since $1981^{7}$. The theoretical foundation of the study rests on the theory of modernisation, which postulates how economic, technological and political changes in industrial and post-industrial societies, acting together, define the mutual relations, lifestyles and values of human beings. The roots of the theory of modernisation go back to the works of Auguste Comte, Herbert Spencer, Karl Marx, Emil Durkheim and Max Weber. This theory formed the backbone of the prediction that growing modernisation would result in a transition from a traditional to more individualised values in all countries. Yet repeated EVSs have showed that cultural differences in countries of a similar level of development are too great. Therefore, the assumption was made that it is culture, national historical context, and not the processes of modernisation, that defines the expression of values.

The American sociologist Ronald Inglehart in his revision of the modernisation theory focused on two transformations. The first is the transition from 'traditional' to 'secular/rational' values driven by industrialisation and the concomitant processes. The second transformation is the transition from 'material/ survival' to 'post-material/self-expression' values ${ }^{8}$. The second transformation is gradual in nature; the social and economic development that goes hand in hand with industrialisation brings security for the people, which means they are able to satisfy their basic existential needs and then proceed to actualise higher needs: those of self-expression. Based on EVS data, the researcher determined that countries can be classified by their proximity to one of the poles of values. For instance, Lithuania and some other post-communist countries were classed as societies with largely prevalent 'secular/rational' values, which are followed by 'material/survival' values. In other words, Lithuanians do not carry a strictly traditional set of rules; they are rather secular and rational, yet still find it important to satisfy their basic needs, which manifest themselves in accentuating material values.

\footnotetext{
${ }^{7}$ Lithuania took part in the study four times: in 1990, 1999, 2008, and 2017.

${ }^{8}$ Inglehart R., Baker W. (2000), Modernization, Cultural Change and the Persistence of Traditional Values, American Sociological Review 65, p. 19-51.
} 
Analysis of data from many countries worldwide has revealed a connection between economic and social progress indicators and the two above value orientations, yet this correlation is not linear, because modernisation proceeds differently from country to country. On top of that, values are affected by the history and social development of a country ${ }^{9}$. Therefore, economic progress, wars, occupations, the experience of authoritarian or democratic rule, religion, traditions - all this taken together defines the type of values embedded in society. Inglehart also highlighted the factor of 'cultural lag', which means that cultural changes (norms, values and so on) lag behind their material (technological, economic and so on) counterparts. For modernisation-driven changes to become apparent, a change of generations needs to take place; it is therefore inaccurate to speak of society in general, for different generations (age groups) can follow slightly different values ${ }^{10}$.

Another author that studied the question of motivation to serve in the military directly through a prism of values was Italian sociologist Fabrizio Battistelli. He identified three systems of soldier motivation: the paleo-modern, the modern and the post-modern. Each type of motivation is different by whose interests - their own or those of the community/state - the soldier prioritises, as well as by the type of needs (basic survival, or higher needs of self-realisation and recognition) he tries to satisfy ${ }^{11}$. According to Battistelli, a soldier with paleo-modern motivation is rather oriented towards the team, the community to which they feel they belong. They find it important to be of service to others, to improve the international image of their country. Soldiers of modern motivation are more oriented towards their own personal needs and tend to focus material things (such as a salary, qualifications acquired in the course of service and so on) more. The former can be conditionally referred to as patriotic idealists, the latter can be seen as professionals who perceive service as a professional endeavour. Of the third type of motivation, post-modern soldiers find it important to experience adventure and challenge and acquire meaningful experience. Just like the modern type, they too are oriented towards satisfying personal needs, although their needs are not material (basic) but those of a higher variety and involve self-realisation.

\footnotetext{
${ }^{9}$ Žiliukaite R., Poviliūnas A., Savicka A. (2016), „Lietuvos visuomenès vertybių kaita per dvidešimt nepriklausomybès metų", Vilnius: Vilniaus universiteto leidykla, p. 14.

${ }^{10}$ The element of cultural lag was defined by W.F. Ogburn in 1922. It is brought to attention in this article, because young people's views on certain matters may differ from those of the society in general. Therefore, the available data permitting, the opinion of young people (men aged 15-30) is always analysed separately from that of the Lithuanian public.

${ }^{11}$ Battistelli F., Peacekeeping and Postmodern Soldier, Armed Forces \& Society, 23 (3), 1997, p. 467-484.
} 
So if we follow Inglehart's analysis of value transformations and Battistelli's concept of the types of soldier motivation, we should now review the values of Lithuanian society and the priorities of young people that could affect their motivation to do PCPMS.

\section{Value Orientations of Lithuanian Society and Young People}

For the purposes of considering the motives that would entice young Lithuanians to serve in the Lithuanian Armed Forces and do compulsory military service, the question could be reworded as follows: What (internalised or latent) needs of young people can be satisfied by military service? And what important things would encourage young people to serve? Both of these questions are about priorities and values.

Society can be defined as a context in which young people socialise. This is the view of society or their closest environment towards the armed forces, and serving in them can act either as a factor that promotes service or one that deters from PCPMS. On the other hand, one part of society - family - as a value per se can become a motivator to serve and defend the country. A survey of the first round of conscripts after the reintroduction of PCPMS showed that the main motive (mentioned by $54 \%$ of the respondents) to do the service was the desire to learn how to defend one's family and motherland should a threat arise.

To draw a value portrait of Lithuanian society and young people in broad strokes, we can rely on the European Values Study made in Lithuania in $2008^{12}$. The question that helps identify the general priorities of society is this: 'How important are the following in your life: family, work, friends and acquaintances, religion, and politics?' As we can see in Figure 2, the Lithuanian public in 2008 prioritised the family, which was followed by work and pastimes and friends and acquaintances. Religion and politics were the least important things in people's lives at that time.

\footnotetext{
${ }^{12}$ At the time of writing this article, data from the fourth EVS conducted in Lithuania in 2017 are not yet available (the data are still at the stage of analysis). As a result, the youth aged 18-24 mentioned in this chapter matches the current age group of 27-33. Unfortunately, the available data from 2008 do not allow us to judge the values of the youngest age group of 18-26. Still, if we follow the assumption that the transformation of values is a slow-going process that spans decades, we should think that the 2008 data more or less accurately reflect the values of the Lithuanian society and youth of today (2018). The data have been obtained from the online database at: https://dbk.gesis.org/EVS/Variables/compview.asp? db=QEVSLF\&id =\&add=ZA4800\&var=\&lang=\&id2=\&var2=\&lang2=\&vsearch=\&vsearch $2=\& \mathrm{~s} 1=1$ \&s $2=1$ \&s $3=1$ \&bool=
} 


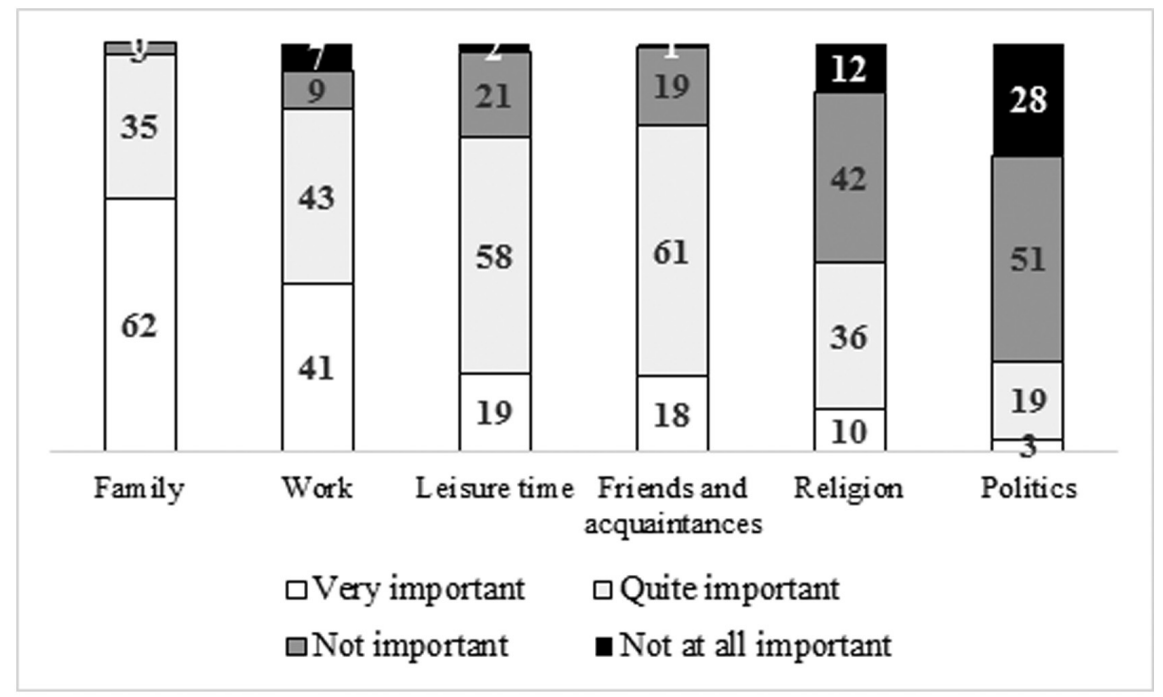

Figure 2. Things that are important in Lithuanian people's lives, 2008 (\%)

$$
(\mathrm{N}=1500)
$$

When we differentiate the answers to this question by age group (see Figure 3), certain differences become evident. Family as a value is emphasised the most by people aged 31-40. Young people aged 18-24 find it less important than other age groups. Likewise, the importance of work rises after the age of 30, and then loses its significance with older age groups. Friends and acquaintances and leisure are accentuated to be the most important things in life by young people (especially those aged $18-24)^{13}$. So it can be said that the opinions of friends and acquaintances can be an important factor affecting the decision of young people to do military service as well.

\footnotetext{
${ }^{13}$ These data of young people are not differentiated by gender and reflect the opinion of men and women alike.
} 

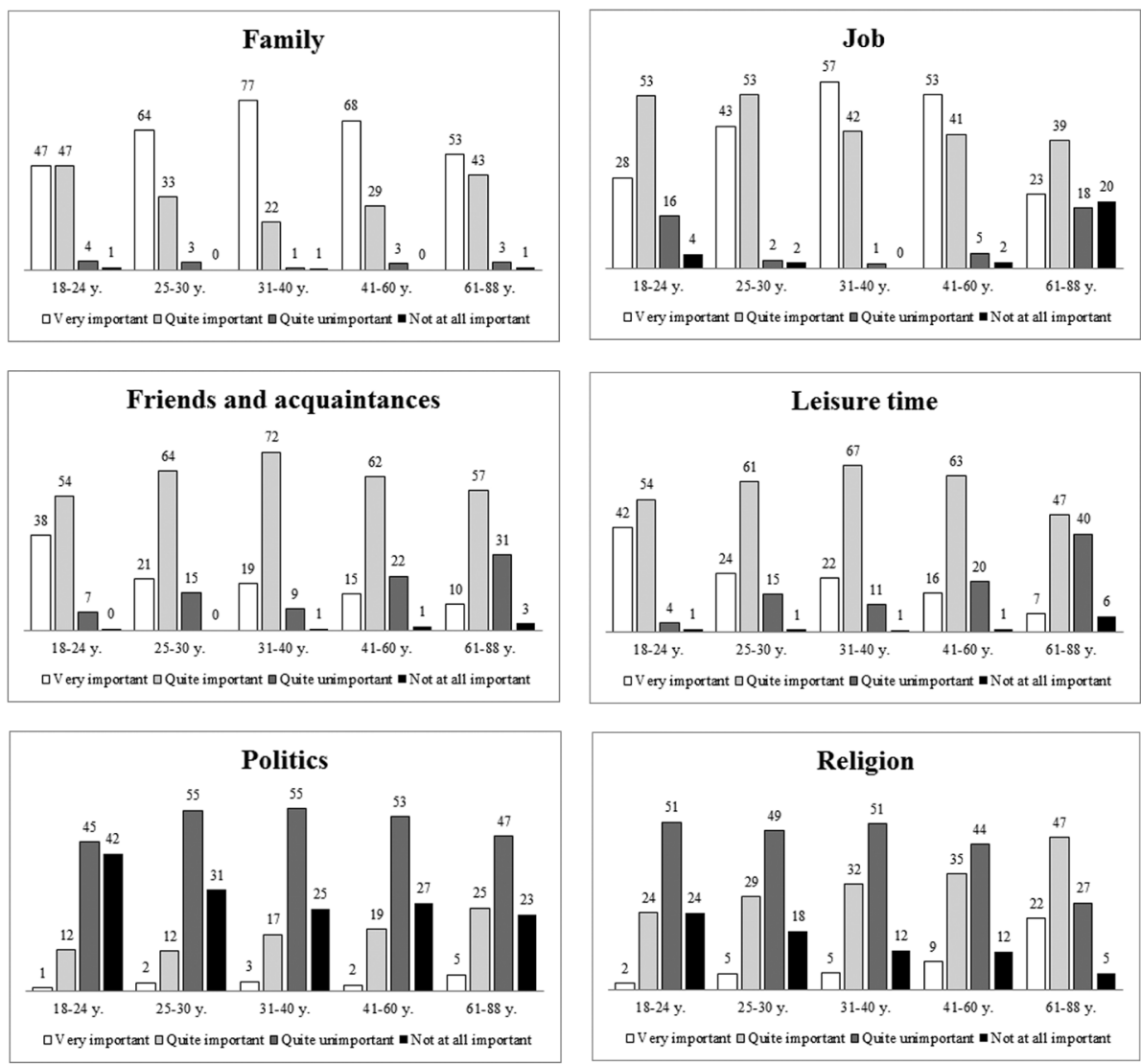

Figure 3. The importance of social aspects of life by age group, 2008 (\%)

Also, the fact that young people aged 18-24 find leisure very important to have in life compared to those in older age groups could lead to the following question: What can the army offer a young person as a meaningful leisure activity? Bearing in mind these distinct differences in the values of young people and society, we should take a closer look at their views towards family, work and leisure.

\subsection{Family as a Value}

The European Values Study does not provide a definition of family. It is for the public (respondents) to decide how it should be defined subjective-

Savicka notes that, just like in Western Europe, Lithuania too underwent a change in the matrimonial and procreative behaviour of its population 
at the turn of the century, with the age of first marriage and having the first child increasing, the number of children in families diminishing and the divorce rate growing. However, in the case of Lithuania (and the other countries of the eastern bloc), these changes began two decades later than in the west. This is why, in the context of Western Europe, Lithuania is still one of the countries that has best preserved the qualities of the traditional family ${ }^{14}$. This is evident in the relatively young age of the first marriage and the low rate of births out of wedlock. Lithuania also stands out in its fostering of traditional values, accentuating the importance of the institute of marriage, upholding the idea of children as the family's duty to society and a woman's meaning in life, differentiating the social roles of men and women under the patriarchal family model. Referring to the results of their studies, the researchers Vida Kanopiené, Sarmite Mikulioniené and Vida Česnuityte observe that family-related value-based attitudes are almost similarly important across all age groups: people regard the family as the centre of life, accentuating support to family members.

How can these results be interpreted in the context of motivations to serve in the military? First of all, the fact that family is the Lithuanian society's main priority in young people's lives is consistently reflected in conscript motivation. As was already mentioned, the principal motivator for volunteer conscripts to serve in 2015-2016 was the desire to learn to defend the family and the country should a threat arise (54\%). Equally, in 2016 this motive was specified by young civilians (males aged 15 to 30 ) as the main reason to do PCPMS (47\%).

Second, if Lithuanians perceive family to cover a broad circle of people, it is the environment that could shape a young person's willingness or unwillingness to do PCPMS as well as their attitude towards the services in general. On the other hand, in the youngest age group (18-24) where family is rivalled by friends and acquaintances, the opinions of the latter can have a higher significance.

Third, family can become a counter-factor to service in the military and PCPMS. This has to do with the age of the population. At age 25 and later, when faced with duties to their new family, young people are apt to be less devoted to service. This has proof in a study of volunteer soldiers conducted by researchers at the MAL Centre for Strategic Research in $2014^{15}$ that revealed the competitive relationship between family and service, when time and attention has to be distributed between 'two greedy institutions'. In the case of the

\footnotetext{
${ }^{14}$ Kanopienė V., Mikulionienė S., Česnuitytè V. (2015), „Lietuvos šeima Europos kontekste“, Vilnius: Mykolo Romerio universitetas.

${ }^{15}$ „Motyvacijos tarnauti Lietuvos kariuomenės krašto apsaugos savanorių pajegose tyrimas“. A study report. Generolo Jono Žemaičio Lietuvos karo akademija, 2014.
} 
nine-month compulsory military service, a young person is virtually removed from a family's life, which is probably why, following the reintroduction of PCPMS, most of the scepticism came from potential conscripts who already had families. Furthermore, considering that Lithuania stands out amidst other European countries in the relatively young age of first marriage, young people aged 25 and over might be difficult to attract as volunteers to do PCPMS compared to other Western European states.

Ergo, family as a value can act both as an encouraging factor (something worth serving for) and as a deferring-from-service, attention-demanding entity. Also, family is an environment where a young person's attitude to service and the army in general takes shape.

\subsection{Work Values}

Compulsory military service cannot be directly tied to work, as it is not a professional activity. On the other hand, PCPMS can be the interim step to becoming a soldier in the professional military service (PMS). According to data from a 2016 conscript survey, $28 \%$ of soldiers noted they volunteered to serve because they wanted to become PMS servicemen and make a career in the military. This leads to a question: Do conscripts perceive professional military service as a traditional job, or is it more of service by calling? This question can be answered indirectly by analysing their perception of the army in general. In the 2016 survey, $52 \%$ of conscripts defined the army as an organisation where people go to serve driven by calling, patriotism, a desire to defend the homeland. Another $37 \%$ believed that the army was a unique and closed organisation, only soldiers capable of grasping how exclusive it is, and only $11 \%$ said that the army is just like any other employer that grants you a profession, a salary and a sense of security. Therefore, only a small percentage of conscripts of the 'first wave' perceived the army as a traditional employer. Despite this, we should look into what Lithuanian society and young people emphasise when they think about work. That way, we will be able to identify their potential expectations in realising military service as work.

Researchers Maria Ros, Shalom Schwartz and Shoshana Surkiss ${ }^{16}$ have noted that work values are an expression of general values in a working environment. They are comparably stable and only change over a prolonged period

\footnotetext{
${ }^{16}$ Ros M., Schwartz H. S., Surkiss Sh. (1999), Basic Individual Values, Work Values and the Meaning of Work, International Association of Applied Psychology 48 (1), p. 49-71.
} 
of time. Inglehart has found that when it comes to work values, Western European countries have eventually gone through a transition from material to post-material values. If work once was primarily valued as a source of income, later it became important for it to allow a person to grow and develop, to be interesting and meaningful. The material values of work tend to retain their significance in less-well-off countries, while rich countries attach more meaning to self-realisation. ${ }^{17}$

Work values are furthermore classified as internal and external. ${ }^{18}$ Persons who focus on internal values find work important as such for it offers opportunities for self-expression. Such people need work to be interesting, creative and challenging, allowing them to make independent decisions, achieve real results and gain recognition. By contrast, people of external orientation consider work as a means to achieve other, non-work-related goals. Such people accentuate material remuneration and good working conditions. Yet empirical studies have shown that these two orientations do not contradict one another and are actually closely interrelated. According to Inglehart's theory of material and post-material values and Abraham Maslow's concept of human needs, internal or postmaterial values only become predominant when the fundamental physiological, material and security needs of the human being are satisfied.

There is another way to classify work values, as instrumental, cognitive and emotional. The first group is typical of externally oriented people who consider work as a means to their ends. These are related to the satisfaction of basic needs and assurance of a sense of security. The second group, cognitive and emotional values, are intrinsic to people of internal orientation who accentuate self-realisation and emotional comfort in work.

So which work values are typical of Lithuanian society? Having analysed the data from the EVSs of 1990, 1999 and 2008, the sociologist Savicka argues ${ }^{19}$ that the Lithuanian public consider work second to family. Yet each EVS shows an increase in the number of people who consider work completely inconsequential. This can be explained through the ageing of the population and the growth of the number of people of retirement age. Younger people tend to attach meaning to the various aspects of work more than the older population. They particularly underline such work values as the possibility to express oneself, acquire new skills, take part in decision-making and so on.

\footnotetext{
${ }^{17}$ Žiliukaitè R., Poviliūnas A., Savicka A. (2016), „Lietuvos visuomenès vertybių kaita per dvidešimt nepriklausomybès metü", Vilnius: Vilniaus universiteto leidykla, p. 69.

${ }^{18} \mathrm{Ibid}$.

${ }_{19}$ Žiliukaitè R., Poviliūnas A., Savicka A. (2016), „Lietuvos visuomenès vertybių kaita per dvidešimt nepriklausomybès metü", Vilnius: Vilniaus universiteto leidykla, p. 72.
} 
According to the results of the 2008 EVS, the aspects of work that were most important to Lithuanian people were: good pay (96\%), interesting work (82\%), job security (72\%), work matching abilities (70\%), pleasant people (66\%), a possibility to mix work and family (66\%), good hours (63\%), equal treatment of all employees (58\%), achieving something at work (54\%), a possibility to gain new skills (52\%), a possibility to socialise, not too much stress (49\%), a possibility to express oneself, show initiative (46\%), generous holidays (43\%), responsible work (42\%), a possibility to be involved in making decisions (37\%), useful for society (32\%). This sequence of priorities shows that in 2008 society was dominated by emotional values, yet the underlying value good pay - was instrumental in nature. Cognitive values that rather reflect a post-modern orientation were seen as less important by the Lithuanian public. Compared to the beginning of the period in 1990, the importance of aspects like job security, responsible work and interesting work had increased significantly. And the importance of decent remuneration had jumped substantially from $79 \%$ to $96 \%$.

A survey of Lithuanian young people (males aged 15-30) conducted at the initiative of the researchers at the MAL CRS eight years later, in 2016, measured the same aspects of work ${ }^{20}$. The data in Figure 4 show that the first two positions hold instrumental values: good pay and social guarantees. Ranking second by importance are the emotional values of job security and interesting work. The cognitive value of the possibility to achieve something at work, to advance up the career ladder placed fifth. Aspects like not too much pressure and public recognition, prestige and the possibility of leadership were mentioned the least.

\footnotetext{
${ }^{20}$ In this survey, there were 4 new aspects added to the original EVS questionnaire: (1) social guarantees (official vacation, sick pay, gratuitous healthcare, and so on); (2) a possibility to travel, to see foreign lands; (3) a possibility of leadership; (4) public recognition (prestige).
} 


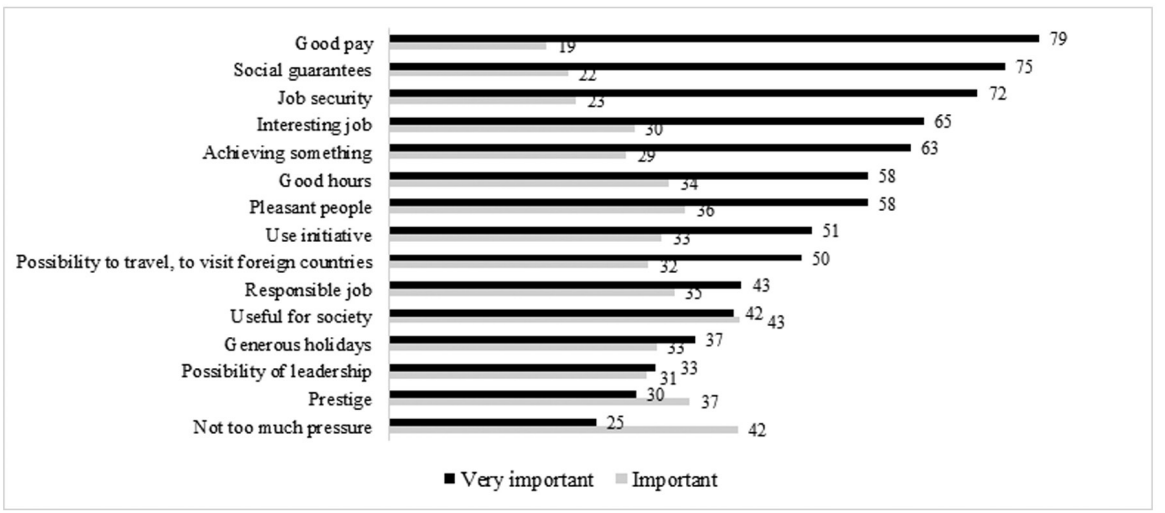

Figure 4. What young Lithuanians (males aged 15-30) consider important about work, 2016 (\%)

These choices by young Lithuanians recorded in 2016 show the prevalence of instrumental values connected to the satisfaction of basic needs. Therefore, young people who see the army as a traditional employer can be trusted to look forward to having these needs satisfied during service.

If professional service can be considered to be work, then there is the question of how compulsory military service that lasts nine months should be defined. Even though this is not leisure directly, one may attempt to define it as free time spent outside of work or family. Savicka observes that the gap between the different levels of importance that different age groups attach to leisure increases with every EVS. She points out that this is indicative of a turning point in the values of different generations. The generation born after 1984 stands out in the hitherto unseen degree of importance it attaches to leisure. According to the 2008 EVS, a whopping $42 \%$ of young people aged 18-24 considered leisure very important. The sociologist argues that these young people are still trying to establish themselves in society and therefore feel a need for self-improvement and tend to accentuate the spontaneous value of leisure more than those who are older. Speaking about leisure, in 2008 the young emphasised aspects like do what you want (49\%), relax (47\%), meet nice people (39\%), learn something new (30\%). Which of these requirements for leisure can be satisfied by military service? For instance, the results of a survey of volunteer troops conducted by the CSR in $2014^{21}$ showed that the underlying motives driving people to serve in the National Defence Volunteer Force were

\footnotetext{
${ }^{21}$ „Motyvacijos tarnauti Lietuvos kariuomenès krašto apsaugos savanorių pajègose tyrimas“. A study report. Generolo Jono Žemaičio Lietuvos karo akademija, 2014.
} 
the desire to experience adventure and challenge (94\%), the desire to defend the homeland in case of a threat (81\%), patriotism (81\%), the desire to spend weekends in a meaningful way (72\%) and a constant interest in soldiership (69\%). Even though these data represent the choices of a wider age group than conscripts alone, they suggest that young people will most probably expect challenge and trials as well as new skills and knowledge from PCPMS as well.

Summing up, we may say that in Lithuanian society, family as value number one could become a stimulus to serve in the military, something worth learning to defend. Furthermore, the greatest degree of volunteerism can be expected from people of a rather young age who do not have any major family-related responsibilities that, compared to Western European countries, tend to appear sooner. Speaking of PCPMS as an interim stage before professional service, and CMS as traditional work, one should note that young people will probably have the following expectations towards service as a place of employment: pay and social guarantees, job security, and an interesting job. By contrast, young people who consider compulsory military service leisure (time spent outside of work and family) will most likely emphasise challenges and trials, possibilities for self-realisation, and acquisition of new knowledge and skills.

\section{The Attitude of Lithuanian Young People and Conscripts to PCPMS and Its Evaluation}

Analysis of what could attract young Lithuanians to do PCPMS cannot be limited to their general priorities alone. One should also look into specific military-related questions such as how much people trust the military, what their opinion of service in the LAF is, what the disposition to defend the homeland in the face of a threat is, and so on. These questions are dissected in the following chapters in two aspects: by comparing the opinions of Lithuanian society and young people (males aged 15-30). Also attention is drawn to the motivation as to why young people have chosen or would choose to do compulsory service voluntarily. For that purpose, the analysis covers two groups: young civilians (males aged 15-30) who have not done PCPMS and 'first-wave' conscripts who volunteered to serve in $2015-2016 .{ }^{22}$

\footnotetext{
${ }^{22}$ A detailed data analysis is presented in the report to the study titled 'Attracting Candidates to the Lithuanian Armed Forces: Issues and Methods to Solve Them' (Lith. Kandidatu i Lietuvos kariuomene pritraukimas: problemos ir jų sprendimo būdai). The Military Academy of Lithuania, 2016.
} 


\subsection{Society and Youth Attitudes towards the Armed Forces, Service and Disposition to Defend the Country}

Considered amidst other Lithuanian institutions, the army is not the institution the public trusts the most, compared to the fire and rescue service, the church, the presidential institution, and so on. However, the positive thing is that Lithuanians tend to trust rather than distrust $\mathrm{it}^{23}$. Data from quantitative surveys show (see Table 1) that society and young men alike were inclined to trust the Lithuanian Armed Forces in 2015-2017. This trust was even more pronounced among young people than it was among the public. With the public, trust was voiced by people with a higher education and higher income as often as not. Despite the brief period of assessment, we can see that the percentage of those who trust the military grew both in society in general and among young people. In the young people's group, the only disparity in 2017 was observed in the opinions of those from Vilnius county, where roughly one-third (36\%) of respondents said they did not trust the military. This distinction could be accounted for by the ethnic profile of the county.

Table 1. Trust of Lithuanian society and young people in the Lithuanian armed forces $(2015,2016,2017)$

\begin{tabular}{|l|c|c|c|c|}
\hline \multicolumn{3}{|c|}{ Do you trust the Lithuanian army? (\%) } \\
\hline & \multicolumn{3}{|c|}{ Society } & \multicolumn{3}{c|}{$\begin{array}{c}\text { Young people (males } \\
\text { aged 15-30) }\end{array}$} \\
& 2015 & 2017 & 2016 & 2017 \\
\hline Trust very much & 12 & 20 & 21 & 26 \\
\hline Fairly trust & 44 & 41 & 42 & 45 \\
\hline Fairly distrust & 20 & 20 & 15 & 17 \\
\hline Don't trust at all & 13 & 7 & 10 & 7 \\
\hline Hard to say & 11 & 12 & 12 & 6 \\
\hline
\end{tabular}

Therefore, the fact that the armed forces is an institution that has people's trust in Lithuania, on the whole, with young people trusting it even more than the rest of the public, is a positive thing when it comes to assessing the possibilities of attracting them to PCPMS. Another question that could be indicative of the disposition to serve in the army is the resolve to defend the homeland in the

\footnotetext{
${ }^{23}$ According to a survey performed by Baltijos Tyrimai in July 2017, the Lithuanian public trusted: the Fire and Rescue Service (82\%), the Church (69\%), the Presidential institution (66\%), the police (65\%), the State Border Guard Service (64\%), the Lithuanian Armed Forces (64\%), the Constitutional Court (61\%), the Lithuanian media (60\%).
} 
face of a threat. In 2016, when asked 'Would you go to defend Lithuania in case of a threat?' $69 \%$ of Lithuanian young men said they would certainly or probably would. After 2017, the question was narrowed down: 'If a threat to Lithuania arose, would you be prepared to defend it with a gun?' Those who would certainly or would probably do it made up 60\%. The drop in the number of people determined to defend their country might have been the product of the stricter wording of the question. It is notable, however, that contrary to young people, the number of the Lithuanian public determined to defend Lithuania with a gun was much lower and stood at $42 \%$. This could be attributed to age, health and other factors.

As the sociologist Egle Vileikiené ${ }^{24}$ has pointed out, the question of disposition to defend the country could be analysed more deeply, linking it to the sense of pride in being a Lithuanian citizen. By connecting two questions, 'Are you or are you not proud to be a Lithuanian citizen?' and 'Should a threat to the homeland arise, would you go and defend Lithuania?', the researcher identified four groups/motivation profiles: (1) patriots, those who are proud of their citizenship and would defend their country; (2) disappointed patriots, those who are not proud of their citizenship but would defend their country, (3) the passive, those who are proud of their citizenship but would not defend their country, and (4) the indifferent and reclusive, those who are not proud of their citizenship and would not defend their country.

Under the same scheme but with the defence question narrowed to, 'Should a threat to the homeland arise, would you defend it with a gun?' the breakdown of the Lithuanian public and youth based on 2017 survey data is shown in Picture 5.

Would defend the state with a gun

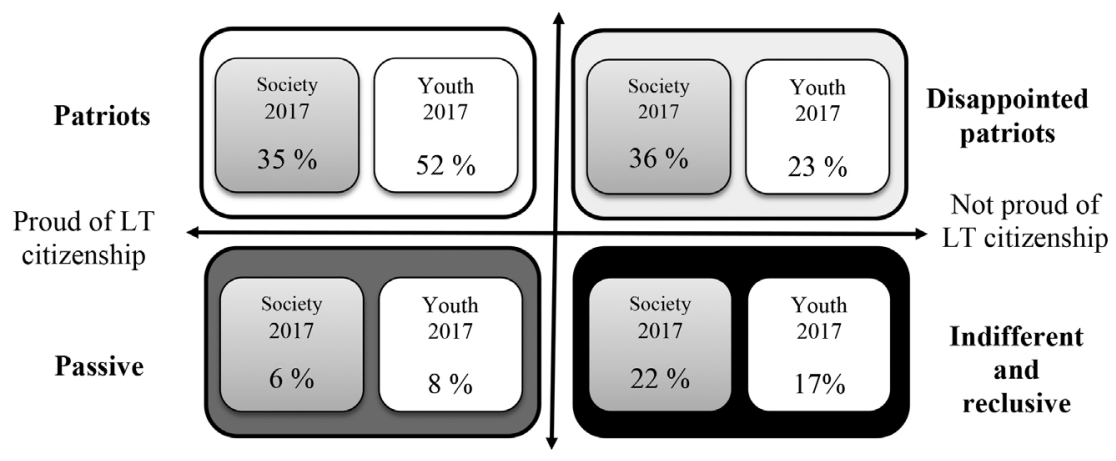

Would not defend with a gun or undecided

Figure 5. Profiles of determination to defend the state with a gun, among Lithuanian citizens and young men

\footnotetext{
${ }^{24}$ „Kandidatų ị Lietuvos kariuomenę pritraukimas: problemos ir jų sprendimo būdai“. A study report. Generolo Jono Žemaičio Lietuvos karo akademija, 2016.
} 
Notably, the percentages of people determined to defend Lithuania with a gun were comparable both among the Lithuanian public and young men, standing at $71 \%$ and $75 \%$, respectively. Only the context of motivation differed: while young men were proud of being Lithuanian citizens more and showed a larger portion of the so-called 'patriots' (52\%), the general public demonstrated a higher degree of disappointment, with only a $35 \%$ share of those who were proud of their Lithuanian citizenship and would defend the country with a gun. $36 \%$ of the population were disappointed patriots who would defend the country but were not proud of their citizenship. Also, the percentage of indifferent individuals who were not proud of being Lithuanian citizens and would not defend their country with a gun was larger among the general public (22\%) than it was among the youth (17\%).

Compulsory military service is one of the ways to teach people to defend their homeland with a gun. In 2016, youth approval of the reintroduction of conscript service was not absolute, with nearly half (48\%) voicing approval yet roughly a quarter (26\%) saying the reintroduction of PCPMS was a negative thing. The main arguments of those who spoke against the reintroduction were the following: Lithuania needs a professional army; military service should be grounded on volunteerism and not compulsion; the Lithuanian army would be unable to defend the country in the face of a threat. Another thing mentioned was that service was keeping young people away from work, college and family. On the other hand, the very same 2016 survey showed that the conscript service was a form of military service that received the largest amount of approval from young people compared to others (see Figure 6). When asked what models of service they would choose, $42 \%$ of young men polled said they would like to volunteer as conscripts and do compulsory military service; slightly over one-third (38\%) said they would want to attend training courses for military specialists while still at college but would not serve in the military after they graduate. The least amount (26\%) of young people wanted to study at the Military Academy of Lithuania and become officers. The situation did not change a great deal in 2017. So it can be said that the majority of young people are not inclined to engage in the military for a long period of time and the nine-month conscript service is, so far, the most acceptable form of military service. 


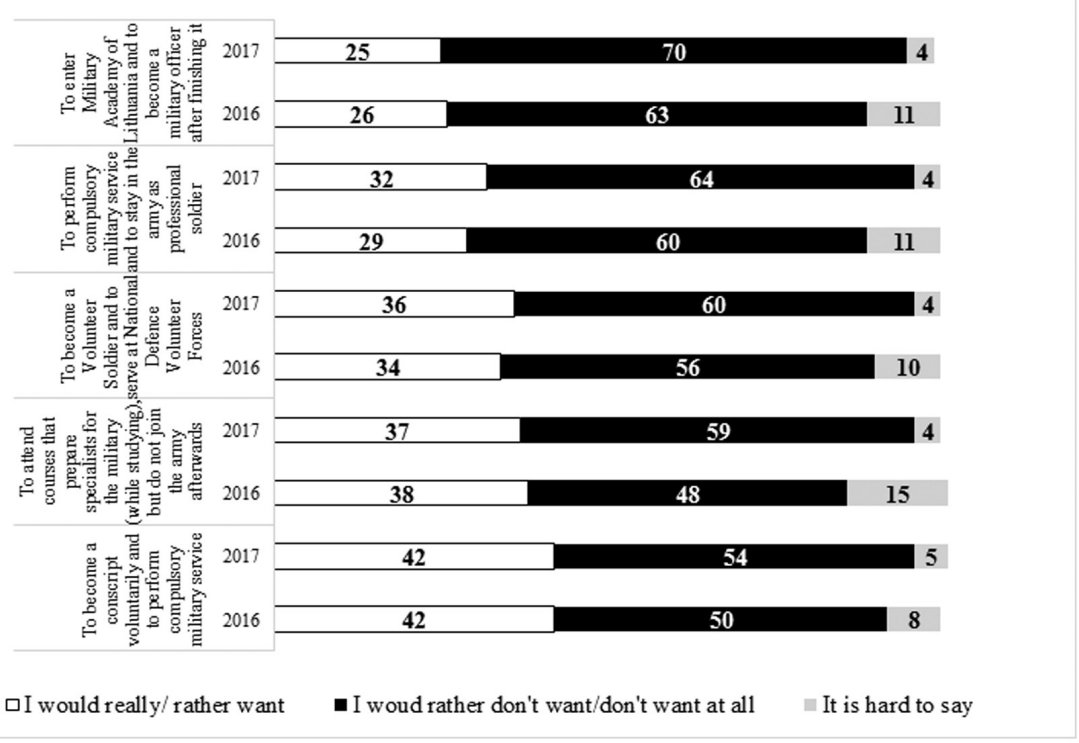

Figure 6. Lithuanian young people's willingness to try different models of service in $2016(\mathrm{~N}=662)$ and in $2017(\%)(\mathrm{N}=607)$

Even though in 2016 more young Lithuanian men were unwilling (43\%) rather than willing (38\%) to do compulsory military service, there was a clearcut connection to age. Younger guys (aged 15-19) were more willing to become conscripts than older guys (aged 26-30), their number standing at respectively $56 \%$ and $26 \%$. This should be attributed to the above-mentioned age phase: older people are more involved in their studies or work, they have family-related responsibilities and fewer possibilities to serve. Interestingly, of the $38 \%$ who wanted to serve as conscripts, more than half $(63 \%)$ were particularly highly motivated, saying they would even serve with no consideration. After a year, in 2017, the percentage of young people who wanted to do PCPMS voluntarily was already smaller (34\%). Yet the number of them who said they were willing to serve with no consideration was close to what had been observed before. This shows that PCPMS appeals to motivated young people for reasons other than reward.

When it comes to making the decision to serve, the support of others is equally important. In 2016, as many as seven out of ten Lithuanian people were willing to agree that someone they knew would serve in the Lithuanian Armed Forces. The agreement was rather more often expressed by men over 46 and people with low or average income.

So the survey data show that the Lithuanian public trusts its military, 
the trust being even more evident in young men. Also, both the general public and young people in particular are inclined to defend their homeland in the face of a threat, although the resolve of the latter group is reinforced by their stronger feeling of pride of being Lithuanian citizens. Furthermore, the youngest Lithuanian men (aged 15-19) are inclined to do PCPMS the most, material consideration not being their primary motivator.

\subsection{Young Civilian and Conscript Motivation to Do PCPMS}

The differences between young people who volunteered or did not volunteer to do PCPMS are best revealed in the process of analysing their determination to defend the country in the face of a threat, as well as the motives as to why they did or would choose to volunteer to serve in the military. Yet first of all we have to consider who and what were these young people who were the first to (largely) volunteer to do PCPMS after it had been reinstated.

The typical 'first-wave' conscript in 2015-2016 was: male (98\%), Lithuanian (94\%), non-married or single (90\%). The average age was 21.7 and the majority $(52 \%)$ of conscripts had secondary or vocational (23\%) education. These were young people without any significant family- or job-related responsibilities who were able to plan their lives with a higher or lower degree of flexibility and devote nine months to compulsory military service. Analysis of the aspect of volunteerism has showed that a portion, albeit small (9\%) of conscripts subjectively realised they were performing a duty and were not volunteers. Another 70\% said they had chosen to serve voluntarily before the conscript lists were published, and one in every five (21\%) conscripts said they filed a priority application when they found out they had been drafted. Some $14 \%$ conscripts had already had some soldiership experience before they were drafted for compulsory service. Most of these had served in the Riflemen's Union while some also mentioned the National Defence Volunteer Forces, shooting clubs and so on.

It is important to highlight that in terms of age most of the conscripts belonged to the so-called generation $\mathrm{Z}^{25}$. This generation relates to the appearance and expansion of new information technologies and the Internet in particular. It is a modern, tech-savvy generation, one that researchers say is

\footnotetext{
${ }^{25}$ Western sociologists have named the generation born in and after 1995 (according to some - in and after 1994 or 1991) 'generation Z'. Targamadzė V. (2014), „Z karta: charakteristika ir ugdymo metodologinès linkmès įžvalga“, Tiltai (4), p. 94-104.
} 
prone to mix actual and virtual realities together ${ }^{26}$. When viewed against the backdrop of military service, it is important that the members of generation $\mathrm{Z}$ are not inclined to blindly obey orders if they do not understand the purpose and the content. Therefore, generation $\mathrm{Z}$ is most likely hardwired to get into conflict while serving in the army, an institution based on subordination and unquestioned compliance. On the other hand, conflicts can be avoided by choosing the right leadership style. In the words of Professor Vilija Targamadze, a researcher of generation $\mathrm{Z}$ :

One must not adulate that generation the way it is sometimes done, one must not widen
the gap between generations. These kids attach great value to speaking from a human
standpoint - most definitely not by looking down on them or trying to impose so-
mething. They are very open and enormously interesting. One simply needs to see how
interesting and good-natured they are, and cooperate with them. ${ }^{27}$

Roughly one-half (52\%) of the original conscripts perceived the army as a patriotic organisation where people go to serve driven by calling or by a desire to protect their homeland. Another $37 \%$ believed that the army was a unique and closed organisation, with only soldiers capable of grasping how exclusive it is. Only one in ten (11\%) said that the army was just like any other employer that grants you a profession, a salary and a sense of security. That was the portrait of the typical conscript in 2015-2016. We should now analyse whether their opinions in different matters differ from those of young civilians (males aged 15-30), and if so, how. This would allow us to understand why the former volunteered to do PCPMS, and the latter did not.

Some differences in the determination to defend the homeland became apparent first and foremost. 56\% of conscripts and 32\% of young civilians were strongly determined to defend Lithuania in the face of a threat (answering the question, 'Would you defend Lithuania in case of a threat?' with 'Definitely yes'). In truth, the enthusiasm of conscripts by the end of their service had waned slightly, with merely $41 \%$ of them saying they would definitely defend the country. On the other hand, the overall rate of approval (respondents replying 'definitely yes' or 'rather yes') was high both at the beginning (81\%) and at the end $(71 \%)$ of service.

Comparing conscripts and young civilians based on the above motivation profiles (pride in Lithuanian citizenship and determination to defend the country, see Figure 7), there were more patriots among conscripts (75\%) than among young people (61\%), the number of disappointed and indifferent

\footnotetext{
${ }^{26} \mathrm{http}: / /$ zinios.lt/lzinios/Mokslas-ir-svietimas/z-karta-tiesiog-kitokie-vaikai/211947 (Accessed on $03 / 05 / 2018)$

${ }^{27} \mathrm{Ibid}$.
} 
conscripts was half that of young civilians ( $8 \%$ and $16 \%$, respectively); fewer conscripts were passive compared to young civilians as well (9\% and 15\%, respectively). This shows that the determination to defend the country was more evident in volunteer conscripts than it was in young civilians straight away.

Would defend the state in the case of a threat

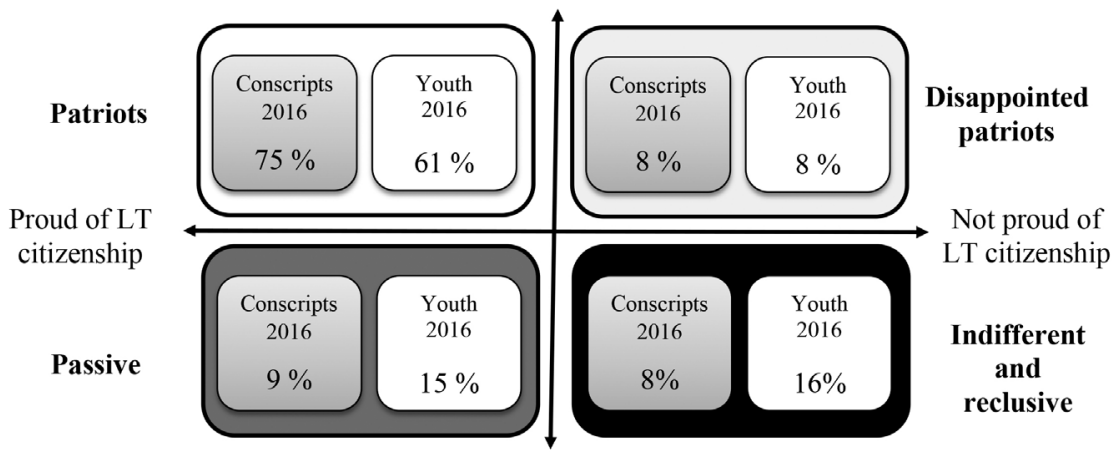

Would not defend or undecided

Figure 7. Profiles of determination to defend the country among young civilians and conscripts

Analysis of the motives driving conscripts and potentially encouraging young civilians to choose PCPMS has also revealed some disparities (see Figure 8). Both with conscripts and young civilians, stimulus number one to enlist is the desire to learn how to defend the family and the motherland in the event of a threat. This reason was more evident among conscripts (54\% vs. $47 \%$ ). Analysis of other reasons also points to a certain number of differences. With conscripts, the second-most important stimulus is the postmodern motive of self-realisation - a desire to experience adventure and a challenge (43\%). By contrast, young civilians would enlist in PCPMS because of a threat to Lithuania (35\%) (this was the least important reason for conscripts (9\%)). Ergo, the civilians' choice is affected by external threats rather than internal motives. And considering that between 2015 and 2017 the percentage of people who believed that Lithuania's security and stability were in jeopardy had dropped from $61 \%$ to $49 \%$, one can understand why the number of volunteer conscripts is on the decline, and there were those who were enlisted by compulsory procedure in the third draft.

Another difference is that there were more recruits (28\%) than young civilians (14\%) who wanted to become soldiers in professional service. Keeping fit as a reason was more important to conscripts (28\%) than to young civilians (23\%). 


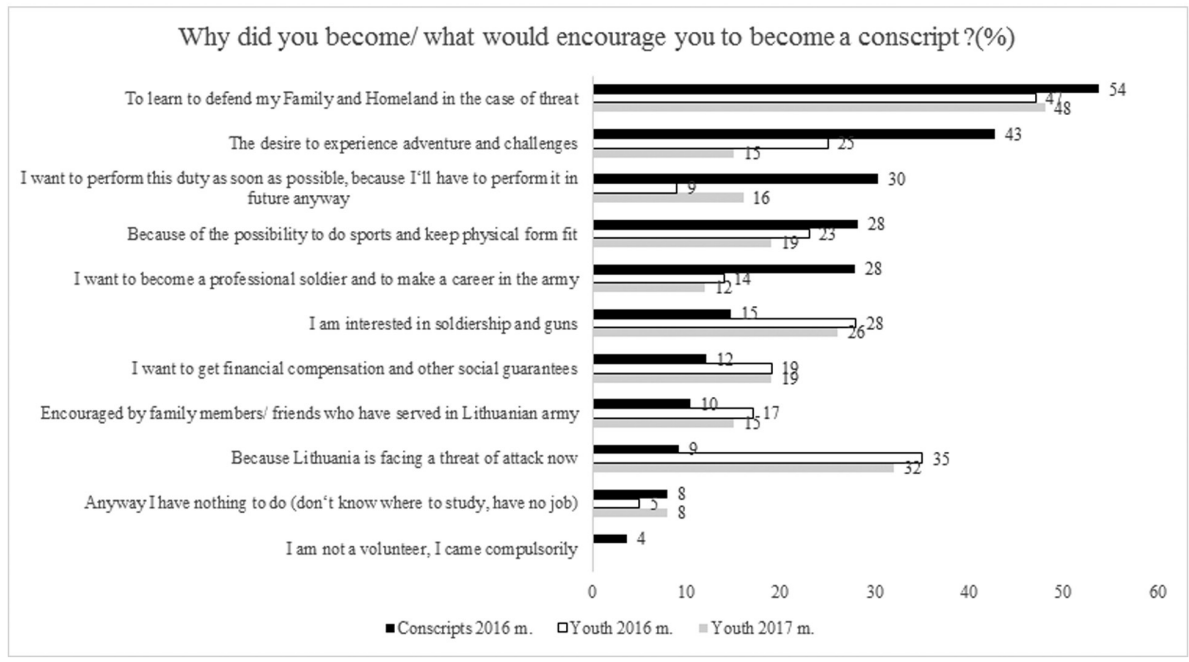

Figure 8. Factors motivating conscripts and young civilians to volunteer to do PCPMS (\%)

Still, when it comes to analysing conscripts' 'volunteerism', we have to admit that a massive $30 \%$ said they wanted to do PCPMS now so they would not have to do it later. This shows that some of the conscript volunteers are driven not by patriotic feelings but by rational reasons. Factors differentiating conscripts' opinions have become apparent as well. One of these is prior experience of soldiership. Conscripts who had prior experience of soldiership (by way of the NDVF, the Riflemen's Union, shooting clubs and so on) were inclined more than the rest to become professional soldiers after they were done with PCPMS. Second, conscripts who believed that Lithuania's security and stability were in jeopardy emphasised the desire to learn to defend their family and homeland more than the majority. Differences in conscript motivation are further defined by the extent to which they were proud to be citizens of Lithuania. Those who were not proud to be citizens of Lithuania specified the desire to perform the duty now lest they had to do it in the future as stimulus number one more often than the rest. Also, those who had a negative opinion of the service from the very beginning mentioned instrumental motives to serve such as the desire to finish the duty as soon as possible and receive monetary compensation and the available guarantees more often than the others.

Ergo, the conclusion can be made that the overarching motive as to why young people do or would do compulsory military service is the desire to learn to defend family and homeland in case of a threat. The main difference between conscripts and young civilians is that the decision of the latter group 
to do PCPMS would largely be affected by the perception of an external threat. Serving in the Lithuanian military as conscripts mainly appeals to the youngest, patriotically minded youth who do not yet have any family-, college- or work-related responsibilities. They are proud to be Lithuanian citizens more than the others and are more determined to defend their homeland in the face of a threat. These conscripts are driven by a clear post-modern motive to experience adventure and challenge and to become physically stronger. Also, they are more determined to become professional soldiers than civilians are. Even though material motives did not affect their resolution much, there is a degree of rational calculation, with a third of them willing to do compulsory service now so that they don't have to do it later.

\subsection{Sources of the Armed Forces and PCPMS}

Understanding the factors or levers that could help attract young people to volunteer for compulsory military service requires more than just grasping their values or attitudes with regard to the army or defending the country. It is also important to evaluate what information young people get about the Lithuanian military and compulsory service, and where they get it from. Following a probe into society's knowledge of the national armed forces, British researchers Emma Parry, Zoe Morrison, Dilys Robinson and Vince Connelly ${ }^{28}$ found that the overall level of society's awareness is quite poor. The main sources of information were word of mouth and media ads. Only those who were interested in the army would gather more information from sources such as Internet websites, former servicemen and army presentation events.

These results are mirrored by data from surveys conducted in Lithuania. A 2016 survey of young people shows that more than half (53\%) would get most of their information about the army from friends, acquaintances and relatives serving in the Lithuanian Armed Forces. Other sources were social media (47\%), TV shows (42\%) and Internet portals (41\%).

The first source is important in a way that friends and relatives in the LAF tend to provide authentic first-hand information. And the message servicemen will deliver to young civilians might decide the latter's choice to serve or not to serve. In 2016, more than half (61\%) of conscripts claimed they would recommend doing PCPMS to their friends and acquaintances, $18 \%$ said they would not, and $22 \%$ failed to voice an opinion. When asked the open-ended

${ }^{28}$ The $14^{\text {th }}$ Biennial Conference of ERGOMAS. Hellenic Army Academy Athens, Greece. 
question of 'What do you think could attract other guys and girls to become conscripts?' (it was answered by $71 \%$ of all conscripts) at the beginning of their service, conscripts gave replies that revealed the following categories of opinions: nearly one-third (31\%) of the answers were about how conscripts should be offered better compensation and social guarantees; another group of answers (21\%) related to targeted and appropriate ads and improving the army's image in the eyes of the public; 14\% stressed there should be order and quality within the military, and another $11 \%$ pointed to the need for self-realisation. Another group of opinions (16\%) was that motivation had to stem from young people themselves and service should be driven by patriotic stimulus.

Several months later, at the end of their service period, the conscripts were asked another open-ended question: 'What changes would you suggest to compulsory military service?' Even though the wording of the question is not comparable to the first, and it was answered by far fewer (38\%) conscripts, the emphasis they placed allows us to trace some changes in opinion. First of all, at the end of the service period conscripts did not emphasise material compensation or incentives. Their focus lay on improving aspects of their service and resolving internal issues: improving commanders' work with conscripts, ensuring order and discipline, providing better food, and so on. Also, there were suggestions with regard to the concept of PCPMS as such, the underlying suggestion being that young people should do compulsory military service right after graduating from school.

These answers show that if in making the choice to do compulsory military service and at the beginning of the service period young people are motivated by instrumental values (compensation, social guarantees, etc.), in the course of the service it is emotional and cognitive values that matter the most, such as the inspiring, respectful and motivating behaviour of the commander; a sense of order and discipline; an opportunity to learn soldiership; a possibility to exercise and become physically stronger; and a possibility to realise oneself. These results are backed up by the fact that in their assessment of the experience earned during the service period, conscripts mentioned benefits such as: I became physically stronger (58\%); I did my duty for my homeland (46\%); I learned military stuff and acquired practical experience (46\%); I learned discipline and punctuality (22\%). Also, just like at the beginning of the service period, at its end too there were those (34\%) who said, 'I am done with my service now and will not have to do it later.

So the main and most impactful source of information about the army, PCPMS included, is first-hand information passed on to young civilians by their family members, friends and peers who have already served in the Lithu- 
anian army and have done compulsory service. Considering that peer opinion is extremely valued and impactful at a young age, it is very important that their 'message' of PCPMS is positive and motivating to serve. And that depends on how satisfied the existing conscripts are with their service.

\section{Conclusions}

Giving a single answer to what would attract young people to volunteer to do compulsory military service is an impossible thing to do. When it comes to evaluating the possibilities to attract conscripts, one must first of all understand the context of values in which young people socialise, and identify the specific young-generation priorities that motivate them to make their decisions. Even though, just like most of society, young Lithuanians too find family and work the most important things in life, peers play an important part in their lives as well. It is the opinion of the latter group on service and the army in general that could become a motivating (or deterring) factor in choosing PCPMS. Family plays a controversial role. On the one hand, it is a value that young people want to learn to defend and would therefore volunteer for compulsory military service. On the other hand, it is the family-related responsibilities that occur at an older age that drive motivation to serve in the army and keep PCPMS significantly down.

The younger generation stands out in the level of significance it attaches to leisure as a part of life separate from working life. When it comes to leisure, in addition to other needs, young people find it important to gain new experience, challenges and trials. Therefore, considering the fact that only a small number of young people perceive PCPMS as a starting point for their future professional career, if compulsory military service were to be presented as a certain 'school of manhood' where the needs of the post-modern generation can be met, the flow of volunteers would possibly increase. All the more as both young civilians and conscripts rather tend to perceive the army as a patriotic organisation and not as a traditional employer. The assumption that service does not represent a job is further supported by the fact that material compensation is not that big a motivator in the course of PCPMS. Young people emphasise cognitive and emotional rather than instrumental values in the process of serving in the military. What they expect from service is order, discipline, an opportunity to learn military stuff, authoritative and inspiring leaders, a possibility to become physically stronger, challenges and trials. Failure to meet these expectations could lower satisfaction with the service. And that could become a critical factor in attracting others to PCPMS, because the 
main source of information about military service for young civilians is friends and acquaintances who have served or are serving there now. To ensure the satisfaction of existing conscripts with their service, one needs to note that many of them belong to the so-called Generation $\mathrm{Z}$ and stand out both in their skills in the field of information technologies and their critical thinking and unwillingness to blindly obey authority as well. This is why the ability of direct commanders to work with this focus group becomes very important.

Some of the most obvious factors that could help motivate the young to do PCPMS, and ones that need to be capitalised upon, are that, compared to the rest of the public, they: trust the Lithuanian Armed Forces more; are more determined to defend the country in case of a threat; and are more proud of their Lithuanian citizenship. The key difference between the young people who have become conscripts and those who have not is that the choice of the latter is more affected by their perception of the threat to the country's security, which the volunteer conscripts did not find that important. The desire to learn to defend family and homeland, and the post-modern motive to experience adventure and challenge, were the main reasons why the first volunteer conscripts enlisted to serve. Still, one has to admit that young men are enticed to do their PCPMS by patriotic idealistic and rationally calculated arguments alike. The wish to do compulsory service now to avoid doing it later was also a significant reason behind the volunteerism during the first draft. The conclusion can be made that this argument will gain significance with the passage of time, especially considering the dropping numbers of volunteers and the conscripts' suggestions to enforce PCPMS right after graduating from school. Young people who have already had some experience of soldiership and those who have (or have had) relatives serving in the Lithuanian Armed Forces stand out in the midst of the general context of conscripts. These young men often enlist to PCPMS with a plan to pursue the future career of a professional soldier.

In closing the discussion, we have to emphasise that the assumptions presented in this article are not conclusive. A lot has changed during the period since the reintroduction of PCPMS. PCPMS has changed in its own right and more experience and skill has been accumulated in working with conscripts. Finally, society has changed too, what with its perception of military threats, understanding of the army's mission, and so on. Therefore, young people's attitudes towards compulsory military service and attracting them to serve in the military still remains a broad field for potential studies in Lithuania. 